\title{
IL-23/Th17 pathway and IL-17A gene polymorphism in Egyptian children with immune thrombocytopenic purpura
}

\author{
Ahlam M. Ismail ${ }^{1 *} \mathbb{D}$, Aliaa M. Higazi ${ }^{2} \mathbb{D}$, Hanan M. Nomeir ${ }^{3}$ and Naglaa M. Farag ${ }^{2}$
}

\begin{abstract}
Background: Immune thrombocytopenic purpura (ITP) is an acquired complex autoimmune thrombocytopenia. Uncontrolled cellular immune response is one of the key triggers for the loss of immune tolerance in ITP patients. The purpose of this study was to investigate the association of IL-23/Th17, IL-17A and IL-17A rs2275913 gene polymorphism with ITP in Egyptian children.
\end{abstract}

Methods: 60 patients with ITP and 50 healthy control children from Minia city- Egypt were involved. Serum levels of IL-23 and IL-17A were determined by enzyme-linked immunosorbent assay. The frequency of Th17 cells was measured using flow cytometer. Genotyping for IL-17A was performed via polymerase chain reaction-restriction fragment length polymorphism.

Results: Comparing children with ITP to controls, serum levels of IL-23 and IL-17A as well as Th17 cells percentage were significantly increased $(p<0.001)$. Also, higher levels of these ILs and Th17 cells percentage were associated with decreased platelet count within ITP patients $(p<0.001)$. Analysis of genotype frequencies for IL-17A rs 2275913 polymorphism and its alleles (A, G) showed no significant difference between cases and controls. Likewise, no significant differences were demonstrated between acute and chronic ITP regarding both IL-17A rs2275913 polymorphism prevalence and levels of IL-23, IL-17A plus Th17 cells percentage. The frequency of A alleles was 85 and $86 \%$ within patients and controls, respectively.

Conclusions: Elevated levels of IL-23, IL-17A and Th17 cells may be involved in ITP pathogenesis while IL-17A polymorphism rs2275913 is not prevalent in Egyptian children with ITP.

Keywords: IL-23, Th17, IL-17A, Polymorphism, ITP, Children

\section{Background}

Immune thrombocytopenic purpura (ITP) is a common acquired autoimmune thrombocytopenic syndrome in children. It is characterized by immune-mediated platelet destruction due to binding of immunoglobulin (Ig) G autoantibodies with platelet glycoproteins (GPs) mostly GPIIb/IIIa and GPIb/IX [1]. The incidence of ITP is

\footnotetext{
* Correspondence: ahlam1967@hotmail.com

1 Minia Maternity and Children University Hospital, Pediatrics department, Faculty of Medicine, Minia University, Minia, Egypt

Full list of author information is available at the end of the article
}

approximately 12 per 100,000 children per year and its associated mortality rate is about $1-3 \%$ per year in severe cases $[2,3]$.

The breakdown in the immune tolerance mechanism with ITP is mainly due to dysregulation in their cellular immune responses [4]. ITP patients have platelet autoreactive $B$ cells but $T$ cells immune abnormalities and cytokine imbalance are involved as well [5]. In this way, excessive stimulation of cytotoxic T-lymphocytes induces autologous platelets destruction [6]. Also, the increased apoptosis of megakaryocytes thus decreased

(c) The Author(s). 2021 Open Access This article is licensed under a Creative Commons Attribution 4.0 International License, which permits use, sharing, adaptation, distribution and reproduction in any medium or format, as long as you give appropriate credit to the original author(s) and the source, provide a link to the Creative Commons licence, and indicate if changes were made. The images or other third party material in this article are included in the article's Creative Commons licence, unless indicated otherwise in a credit line to the material. If material is not included in the article's Creative Commons licence and your intended use is not permitted by statutory regulation or exceeds the permitted use, you will need to obtain permission directly from the copyright holder. To view a copy of this licence, visit http://creativecommons.org/licenses/by/4.0/ The Creative Commons Public Domain Dedication waiver (http://creativecommons.org/publicdomain/zero/1.0/) applies to the data made available in this article, unless otherwise stated in a credit line to the data. 
platelet production mediated by $\mathrm{CD} 8^{+} \mathrm{T}$ cells has been linked to ITP [7]. An additional mechanism for loss of peripheral immune tolerance is defective suppressive function or decreased number of a distinct subpopulation of $\mathrm{CD} 4^{+} \mathrm{T}$ cells called regulatory $\mathrm{T}$ cells (Treg) [7]. Moreover, uncontrolled T-helper (Th) cells play crucial roles in the pathogenesis of ITP $[7,8]$.

Th17 cells are regarded as promoters of autoimmune conditions as they produce a number of proinflammatory cytokines containing IL-17A accordingly induce tissue damage [9]. IL-17A is a member of a cytokine family of six cytokines: IL-17A-F. IL-17A uses the IL-17 receptor A (IL-17RA)-IL-17RC heterodimer for signaling [10]. IL-17RA is expressed on hematopoietic cells at high levels [11]. This has led to an interest in using IL-17A as therapeutic target in hematologic disorders [12]. The imbalance of Th17/Treg toward Th17 cells has been shown to play an important role in the peripheral immune response [13, 14]. IL-23 is crucial for maintenance and expansion of Th17 [15]. Releasing IL$17 \mathrm{~A}$ in response to IL-23/Th17 targets mainly mesenchymal and myeloid cells. It could promote the production of a variety of pro-inflammatory or hematopoietic cytokines, chemokines, matrix metalloproteinases plus effecting the expansion of neutrophil through granulocyte colony-stimulating factor (G-CSF) and chemotaxis (CXC), thus aggravating the immunologic derangement characteristic of ITP [16].

Previous studies showed that IL-23/Th17 pathway and increased expression of $I L-17 A$ as well as $I L-17 A$ gene polymorphism have been associated with various autoimmune diseases [17], such as primary biliary cirrhosis [18], inflammatory bowel disease [19, 20], rheumatoid arthritis [21-23] and ulcerative colitis [21, 24]. However, the role of Th17 and IL-23 in the pathogenesis of ITP was only reported in limited number of studies $[25,26]$. Furthermore, the significances of IL-17A and its genetic variations in children with ITP remain uncertain particularly when referred to distinct/regional population groups like Egyptian children [27].

In the present study, we estimated the frequency of Th17 cells in addition to serum levels of both IL-23 and IL-17A in children with primary ITP compared to healthy controls. On top, we compared their measurements between children with acute and chronic ITP. The association between $I L-17 A$ rs2275913 gene polymorphisms and ITP susceptibility, its chronicity along with severity was evaluated as well.

\section{Methods}

\section{Subjects and clinical data collection}

The current study is a case control one that was conducted in the Hematology Unit, Department of Pediatrics, Minia Maternity and Children University
Hospital, Egypt. A total of 110 children were included, 60 children with primary ITP and 50 age and sex matched apparently healthy children as a control group. After obtaining clearance from the Faculty of Medicine, Minia University ethical committee, a written informed consent was signed from the parents or guardians of the children.

Patients were diagnosed based on the presence of bruising and/or petechiae or mucous membrane bleeding, platelet count $<100 \times 10^{9} / \mathrm{L}$ and increased or normal count of megakaryocytes in bone marrow aspirates [28]. Children with active infection, splenomegaly, lymphadenopathy, and any other underlying diseases which may cause thrombocytopenia were excluded from the study. We also excluded infants aged less than 6 months.

ITP patients were receiving a treatment protocol according to guidelines of the American Society of Hematology 2019 for immune thrombocytopenia [28]. Follow-up of patients was carried out to detect remission or progression of the persistent or chronic course of the disease. Three forms of ITP are distinguished according to duration of disease from the onset of the illness: acute $<3$ months, persistent 3-12 months, and chronic > 12 months. ITP severity had classified according to platelets count into very severe $=$ platelet count $<10 \times 10^{9} / \mathrm{L}$; severe $=$ platelet count $10-30 \times 10^{9} / \mathrm{L}$; moderate $=$ platelet count $30-50 \times 10^{9} / \mathrm{L}$, and mild $=$ platelet count $>50 \times$ $10^{9} /$ L. [28]

All enrolled children underwent detailed history taking and clinical examination plus routine investigations. As well, laboratory workup was performed to all subjects including complete blood count using automated cell counter Sysmex diagnostic, USA. Also, examination of Leishman-stained peripheral blood smears and bone marrow aspiration smears were carried out. Our Hematology Unit protocol recommend bone marrow aspiration to all suspected ITP patients to rule out leukemia, myelodysplastic syndrome, or aplastic anemia especially because some of our ITP patients presented with anemia beside thrombocytopenia. Additionally, we use steroids as first line therapy due to the cost price of intravenous immunoglobulin (IVIG) [29].

\section{Laboratory investigations}

Human IL-23 enzyme-linked immunosorbent assay (ELISA) Kit (abcam, United Kingdom) and human IL17A ELISA Kit (Quantikine, Bio-Techne Ltd) were used for quantitative measurement of IL-23 and IL-17A serum levels; respectively. The detection protocols were performed according to the manufacturers' instructions. Levels of ILs were expressed as $\mathrm{pg} / \mathrm{mL}$.

Flow cytometer (BD Biosciences, USA) was used to detect the frequency of Th17 cells. $\mathrm{CD}^{+} \mathrm{CD}^{+}$cells 
positive for IL-17 were recognized as Th17 cells. Heparinized whole blood was surface stained with PE/Cy7-labeled monoclonal anti-CD4 and APC-labeled monoclonal anti-CD3 antibodies (BD Biosciences, USA). Then, red blood cells were lysed using FACS lysing buffer (BD Biosciences, USA). Afterwards, cells were washed with phosphate buffered saline (PBS, pH 7.2, $0.15 \mathrm{M}$ ), fixed with a fixation buffer from Leucoperm, ABD Serotech, USA followed by washing again for 2 times with PBS. The cells were later permeabilized with permeabilization buffer (Leucoperm, ABD Serotech, USA) and stained with phycoerythrin-(PE) labeled monoclonal antibodies against IL-17A. Subsequently, flow cytometry analysis was performed in $\mathrm{CD}^{+}$lymphocytes gate [30].

$I L-17 A$ rs2275913 polymorphism genotyping was detected by the polymerase chain reaction-restriction fragment length polymorphism (PCR-RFLP) technique. DNA was extracted from whole blood using QIAamp DNA blood Mini Kit from Qiagen Inc., Germany. The following primers were used; forward 5 '-TCT CCA TCT CCA TCA CCT TTG-3'and reverse 5'-GTC CAA ATC AGC AAG AGC ATC-3'. PCR products were digested using XagI (New England BioLabs, England) and digested amplicons were separated via electrophoresis with agarose gel (2\%) [27].

\section{Statistical analysis}

The analysis of the data was carried out using the IBM SPSS 20.0 statistical package software. Normality of the data was tested using the Shapiro-Wilk or KolmogorovSmirnov tests. Data were expressed as mean \pm standard deviation (SD), minimum and maximum of range for quantitative parametric measures or median and range for quantitative non-parametric measures in addition to both number and percentage for categorized data. The Student $\mathrm{t}$-test was used for comparison between two independent groups for parametric data and MannWhitney test for non-parametric data. For comparison between more than two independent groups, analysis of variance (ANOVA) was used for comparison for parametric data. Chi-square test or Fisher's exact test were used to compare categorical variables. Correlations between the parameters were analyzed by Pearson's correlation analysis. Correlation coefficient was considered weak if $r=0-0.24$, fair if $r=0.25-0.49$, moderate if $r=$ $0.5-0.74$ and strong if $r=0.75-1$. A $p$-value less than 0.05 was considered significant.

\section{Results}

\section{Demographic and laboratory data of studied groups}

The study included 60 children with ITP (male/female, $38 / 22$; Age range 1-12 years) attending our Pediatric Hematology Unit and 50 healthy controls (male/female,
24/26; Age range 1-14 years). Platelet count in ITP patients ranged from $9 \times 10^{9} / \mathrm{L}-67 \times 10^{9} / \mathrm{L}$, with median platelet count of $22 \times 10^{9} / \mathrm{L}$ at initial diagnosis. Demographic and laboratory data of all patients and healthy controls are shown in (Table 1). Compared to healthy controls, statistically significant lower platelet count and hemoglobin concentration along with higher Mean platelet volume (MPV), Th17 cells percentage, and serum levels of IL-23 and IL-17A were detected in ITP patients (Table 1). Regarding Th17, IL-23 and IL-17A, we found no statistically significant difference in their levels in chronic ITP patients when compared with those with acute ITP (Table 2).

\section{Presenting symptoms and therapeutic regimens of included ITP children}

$50 \%$ of patients had prior viral infections and $80 \%$ had cutaneous bleeding in the form of purpura or ecchymosis. Bleeding per gums or epistaxis were presented in $36.7 \%$ of patients. Intracranial hemorrhage occurred in two chronic ITP patients (3.3\%) who had very severe thrombocytopenia.

Patients with ITP were treated as recommender per the American Society of Hematology 2019 guidelines [28]. In the current study, 52 children (86.7\%) received steroids, 10 patients $(16.7 \%)$ received IVIG and 8 children with chronic ITP (13.3\%) treated with azathioprine (Immuran). We added eltrombopag (Revolade) to 18 children with chronic ITP (30\%). Four chronic patients underwent splenectomy (6.7\%).

\section{Correlation between IL-23, IL-17A, Th17 cells and platelet count in ITP group}

Table 3 shows that IL-23 levels have significant positive correlation with IL-17A levels and Th17 cells percentage in ITP cases. Similarly, IL-17A is shown to be positively correlated with Th17 cells percentage in patients' group $(p<0.001)$ (Table 3). Though, negative correlations are shown between platelet count and both IL-23 and IL17A within ITP patients (Table 3). Figure 1 shows the fair statistically significant negative correlation between Th17 cells percentage and platelets' count in ITP patients' group $(\mathrm{r}=-0.431 \& p<0.001)$.

Table 4 shows the genotype and allele frequency of $I L$ $17 A$ rs2275913 polymorphism in ITP cases. In ITP patients, the genotype frequencies of $I L-17 A$ rs2275913 polymorphism were AA (76.7\%), AG (16.7\%), and GG (6.6\%). While the genotype frequencies of $I L-17 A$ rs2275913 polymorphism in the control group, were AA (72\%) and AG (28\%). There were no statistically significant differences between frequencies of the three $I L-17 \mathrm{~A}$ rs2275913 genotypes in ITP patients compared to control group. In addition, although $I L-17 A$ rs2275913 GG genotype was only found in cases, the difference of 
Table 1 Demographic and laboratory data of patients and controls

\begin{tabular}{|c|c|c|c|}
\hline Parameter & $\begin{array}{l}\text { ITP patients } \\
(N=60)\end{array}$ & $\begin{array}{l}\text { Control } \\
(N=50)\end{array}$ & $P$-value \\
\hline Age (year) & & & 0.345 \\
\hline Range & $1-12$ & $1-14$ & \\
\hline Mean $\pm S D$ & $5 \cdot 5 \pm 3 \cdot 2$ & $6 \cdot 8 \pm 3.9$ & \\
\hline Sex & & & 0.254 \\
\hline Male & $38(63.3 \%)$ & $24(48.0 \%)$ & \\
\hline Female & $22(36.7 \%)$ & $26(52.0 \%)$ & \\
\hline Weight centile (th) & & & 0.09 \\
\hline Range & $75-90$ & $75-80$ & \\
\hline Mean \pm SD & $49.8 \pm 20.8$ & $47.8 \pm 18.5$ & \\
\hline Length/Heigh centile & $e^{(t h)}$ & & 0.07 \\
\hline Range & $50-75$ & $50-75$ & \\
\hline Mean \pm SD & $64.8 \pm 11.6$ & $61.24 \pm 12.4$ & \\
\hline Residence & & & 0.234 \\
\hline Rural & $32(53.0 \%)$ & $28(56.0 \%)$ & \\
\hline Urban & $28(47.0 \%)$ & $22(44.0 \%)$ & \\
\hline $\mathrm{Hb}(\mathrm{gm} / \mathrm{dL})$ & & & $<0.001^{*}$ \\
\hline Range & $7-11.5$ & $11-12.4$ & \\
\hline Mean \pm SD & $9.1 \pm 1.2$ & $11.6 \pm 0.4$ & \\
\hline WBCs $\times 10^{9} / \mathrm{L}$ & & & 0.354 \\
\hline Range & $4-13$ & $4.8-13.6$ & \\
\hline Mean \pm SD & $6.8 \pm 2$ & $7.3 \pm 2.7$ & \\
\hline Platelets $\times 10^{9} / \mathrm{L}$ & & & $<0.001^{*}$ \\
\hline Range & $9-67$ & $218-461$ & \\
\hline Mean \pm SD & $52.9 \pm 25.6$ & $280.3 \pm 46.4$ & \\
\hline$M P V, f l$ & & & $0.006^{*}$ \\
\hline Range & $9.4-11.4$ & $7.7-8.9$ & \\
\hline Mean \pm SD & $11.2 \pm 1.6$ & $7.9 \pm 5$ & \\
\hline Th17 (\%) & & & $<0.001^{*}$ \\
\hline Range & $1-3.9$ & $0.3-1.9$ & \\
\hline Mean \pm SD & $2.1 \pm 0.9$ & $1.1 \pm 0.4$ & \\
\hline IL-23 (pg/mL) & & & $<0.001^{*}$ \\
\hline Range & 109.6-378.6 & $34.9-140.7$ & \\
\hline Mean \pm SD & $215.4 \pm 79$ & $86.4 \pm 32.7$ & \\
\hline IL-17A (pg/mL) & & & $<0.001^{*}$ \\
\hline Range & $40.7-369$ & $31-191.9$ & \\
\hline Mean \pm SD & $92.4 \pm 39$ & $42.7 \pm 19$ & \\
\hline
\end{tabular}

$N$ number, $S D$ standard deviation, $H b$ hemoglobin, WBCs white blood cells, MPV mean platelets volume

${ }^{*} p$-value $<0.05=$ significant

genotype frequency between patients and normal controls did not reach statistic difference. The frequency of allele A of $I L-17 A$ rs 2275913 was $85 \%$ in the cases group and $86 \%$ in the control group. Similarly, the frequency of
Table 2 Laboratory data of acute and chronic ITP patients

\begin{tabular}{|c|c|c|c|}
\hline \multirow[t]{3}{*}{ Parameter } & \multicolumn{2}{|l|}{ ITP } & \multirow{3}{*}{$\begin{array}{l}p- \\
\text { value }\end{array}$} \\
\hline & $\begin{array}{l}\text { Acute }(<3 \mathrm{~m}) \\
(N=26)\end{array}$ & $\begin{array}{l}\text { Chronic }(>12 \mathrm{~m}) \\
(N=28)\end{array}$ & \\
\hline & Median (range) & Median (range) & \\
\hline $\mathrm{Hb}(\mathrm{gm} / \mathrm{dL})$ & $9(8-11)$ & $9(7-11.5)$ & 0.713 \\
\hline WBCs $\left(\times 10^{9} / \mathrm{L}\right)$ & $6.2(4-9.7)$ & $6(4.5-9)$ & 0.593 \\
\hline PLTs $\left(\times 10^{9} / \mathrm{L}\right)$ & $19(9-55)$ & $23(11-67)$ & 0.789 \\
\hline Th17 (\%) & $1.7(1-3.6)$ & $2.1(1-3.6)$ & 0.467 \\
\hline IL-23 (pg/mL) & $183.6(110.3-345.7)$ & 219 (109.6-353.3) & 0.662 \\
\hline IL-17A (pg/mL) & $82.1(42.3-191.9)$ & 117.6 (40.7-173.9) & 0.961 \\
\hline
\end{tabular}

allele G was $15 \%$ in the cases group and $14 \%$ in the control group.

Table 5 shows the genotype and allele distribution among three ITP subgroups. These subgroups were subdivided according to the course of ITP into acute, persistent, and chronic ITP. No statistically significant differences were found when these subgroups were compared to each other. In addition, we investigated the association of the $I L-17 A$ rs2275913 genotypes with some clinical features of ITP. There was no significant association between the frequencies of the genotypes and gender, age, or degree of ITP severity (Table 6).

\section{Discussion}

Our study included 110 children: 60 children with ITP and 50 healthy controls. There were statistically significant lower platelet count and hemoglobin concertation in ITP patients compared to healthy controls which agrees with the results of El Husseiny et al. 2018 [31]. They found statistically significant lower platelet count along with hemoglobin levels in cases rather than controls. Decreased hemoglobin concentrations in ITP patients can be due to nutritional iron deficiency anemia and/or blood loss because of frequent bleeding attacks.

Moreover, our results showed significant increase in MPV in ITP children when compared to control group which is similar to data in the study done by Baig 2015 [32] who found significant increase in MPV within ITP patients and recommended the use of platelet indices as

Table 3 Correlation between IL-23, IL-17A, Th17 and platelet count within ITP group

\begin{tabular}{llllll}
\hline Parameter & \multicolumn{2}{l}{$\mathrm{IL-23}(\mathbf{p g} / \mathrm{mL})$} & & \multicolumn{2}{l}{$\mathrm{IL}-17 A(\mathbf{p g} / \mathrm{mL})$} \\
\cline { 2 - 3 } \cline { 6 - 7 } & $\mathbf{r}$ & $\boldsymbol{p}$ & & $\mathbf{r}$ & $\boldsymbol{p}$ \\
\hline IL-17A $(\mathrm{pg} / \mathrm{mL})$ & 0.744 & $<0.001^{*}$ & - & - \\
Th17 (\%) & 0.987 & $<0.001^{*}$ & & 0.758 & $<0.001^{*}$ \\
Platelet count & -0.393 & $<0.001^{*}$ & & -0.210 & $<0.001^{*}$ \\
\hline
\end{tabular}

${ }^{*} p$-value $<0.05=$ significant 


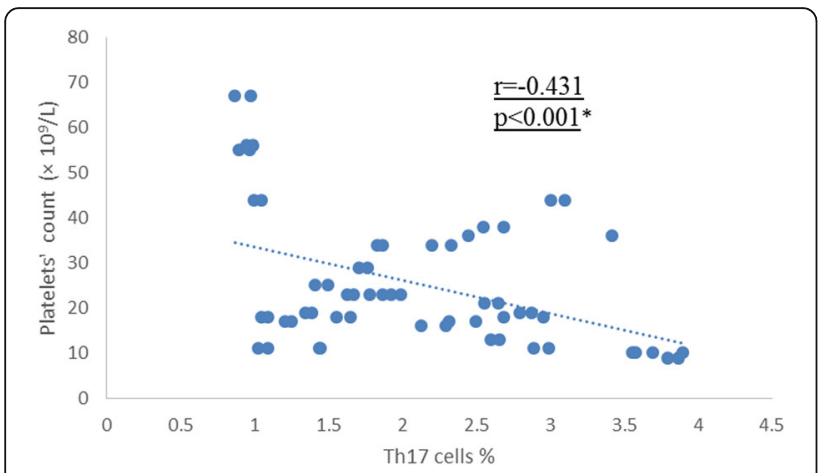

Fig. 1 Correlation between Th17 cells percentage and platelet count within ITP patients. There was statistically significant fair negative correlation between Th17 cells percentage and platelet count in patients group $(r=-0.431 \& p<0.001)$. ${ }^{*} p$-value $<0.05=$ significant

a diagnostic tool to differentiate ITP from acute leukemias.

T-cell is important in the pathogenesis of ITP [33]. The Th17 cell, which produces IL-17, is a subset of $\mathrm{T}$ helper cells. Th17 cells play an important role in T-cellmediated diseases hence may play a role in ITP [34]. As a classical autoimmune disorder, ITP has also been reported to have an aberrant Th17 profile [35].

Higher Th17 cells percentage were detected in the present study within ITP patients in comparison to healthy controls. This comes in agreement with Rocha et al. 2013 [36], who reported that Th17 cells were significantly higher in active ITP patients than that in healthy controls. Likewise, the study of Zhang et al. 2009 [37] showed increased levels of circulating Th17 cells in children with chronic ITP compared to healthy controls. Moreover, we detected higher serum levels of IL-23 in ITP children than controls. This comes in harmony with the results of Ye et al. 2015 [25], who also found increased levels of IL-23 in patients with primary ITP compared to healthy controls. They concluded that IL23/Th17 pathway may be involved in the pathogenesis of ITP through enhancement of the Th17 response.

Th17 cells and their characteristic IL-17A cytokine are considered the initiators of various autoimmune conditions [9]. This has led to an interest in using them as

Table 4 Genotype frequency of IL-17A gene in patients and control

\begin{tabular}{lllll}
\hline Parameter & ITP & Control & OR (95\% Cl) & $\begin{array}{l}\boldsymbol{p} \text { - } \\
\text { value }\end{array}$ \\
IL-17A genotype & $\mathbf{N}(\%)$ & $\mathbf{N}(\%)$ & & 0.639 \\
\hline AA & $46(76.7 \%)$ & $36(72.0 \%)$ & $1.28(0.38-4.31)$ & 0.315 \\
AG & $10(16.7 \%)$ & $14(28.0 \%)$ & $0.51(0.14-1.88)$ & 0.315 \\
GG & $4(6.6 \%)$ & $0(0.0 \%)$ & NA & NA \\
A alleles & $102(85.0 \%)$ & $86(86.0 \%)$ & - & - \\
G alleles & $18(15.0 \%)$ & $14(14.0 \%)$ & & \\
\hline
\end{tabular}

$\mathrm{N}$ number, $\mathrm{Cl}$ confidence interval $N A$ non applicable
Table 5 Relation between outcome of ITP and IL-17A genotypes

\begin{tabular}{lllll}
\hline Parameter & $\begin{array}{l}\text { Acute ITP } \\
(<\mathbf{3} \mathbf{m}) \\
\mathbf{N = 2 6}\end{array}$ & $\begin{array}{l}\text { Persistent ITP } \\
(\mathbf{3}-1 \mathbf{2} \mathbf{m})\end{array}$ & $\begin{array}{l}\text { Chronic ITP } \\
(>\mathbf{1 2} \mathbf{m})\end{array}$ & $\begin{array}{l}\boldsymbol{p} \text { - } \\
\text { value }\end{array}$ \\
& $\mathbf{N}(\%)$ & $\mathbf{N}(\%)$ & $\mathbf{2 8}$ & \\
\hline AA & $22(84.6 \%)$ & $4(66.7 \%)$ & $20(71.4 \%)$ & 0.578 \\
AG & $4(15.4 \%)$ & $2(33.3 \%)$ & $4(14.3 \%)$ & 0.618 \\
GG & $0(0.0 \%)$ & $0(0.0 \%)$ & $4(14.3 \%)$ & NA \\
\hline
\end{tabular}

$N$ number, $N A$ non applicable

therapeutic targets in these disorders [12]. The expression of $I L-17 A$ gene can be upregulated by stimulation with potent IL-23 leading to Th17 differentiation and active release of IL-17 family of cytokines in T lineage lymphocytes [38].

Higher IL-17A levels in ITP children than controls were found in our study. This comes in concordance with the results of El Husseiny et al. 2018 study [31]. They reported higher expression of IL-17 and explained this by the effect of using immune suppressors or upregulation of their receptors on Treg cells which have resistance to their activity. In contrast, Hunag et al. 2015 [39] found that IL-17 levels are indifferent between chronic ITP and normal controls. Different population and group of patients may explain this contradictory.

Furthermore, our results revealed that IL-23 level has significant positive correlation with IL-17A levels and Th17 cells percentage in ITP cases besides serum levels of IL-17A is positively correlated with the percentage of Th17 cells in patients as well. This positive correlation can suggest that IL-17 production is influenced by IL-23. Reversely, negative correlation was found between IL-23, Th17 cells percentage along with IL-17A and platelets

Table 6 Relation of age, sex, and degree of thrombocytopenia with IL-17A genotypes

\begin{tabular}{|c|c|c|c|c|}
\hline \multirow[t]{3}{*}{ Parameter } & \multicolumn{3}{|c|}{ IL-17A Genotype } & \multirow{3}{*}{$\begin{array}{l}p- \\
\text { value }\end{array}$} \\
\hline & $\overline{\mathrm{AA}}$ & AG & GG & \\
\hline & $N=46$ & $N=10$ & $N=4$ & \\
\hline \multicolumn{4}{|l|}{ Age (years) } & \multirow[t]{3}{*}{0.266} \\
\hline Mean $\pm S D$ & $6.7 \pm 3.5$ & $7 \pm 3.7$ & $11 \pm 1.4$ & \\
\hline (Range) & {$[2-12]$} & {$[1-10]$} & {$[10-12]$} & \\
\hline \multicolumn{5}{|l|}{ Sex } \\
\hline Male & $28(60.9 \%)$ & $6(60.0 \%)$ & $4(100.0 \%)$ & \multirow[t]{2}{*}{0.820} \\
\hline Female & 18 (39.1\%) & $4(40.0 \%)$ & $0(0.0 \%)$ & \\
\hline \multicolumn{5}{|c|}{ Thrombocytopenia } \\
\hline Very severe & $0(0.0 \%)$ & $2(20.0 \%)$ & $0(0.0 \%)$ & \\
\hline Severe & $28(60.9 \%)$ & $8(80.0 \%)$ & $4(100.0 \%)$ & \multirow[t]{3}{*}{0.380} \\
\hline Moderate & $12(26.1 \%)$ & $0(0.0 \%)$ & $0(0.0 \%)$ & \\
\hline Mild & $6(13.0 \%)$ & $0(0.0 \%)$ & $0(0.0 \%)$ & \\
\hline
\end{tabular}

$N$ number, SD standard deviation 
count in ITP patients. This comes in line with El Husseiny et al. 2018 [31] and Ye et al. 2015 [25] studies. They found positive correlations between IL-23 levels along with levels of IL-17 and Th17 cells percentage in ITP patients, while negatively related to platelet counts. They suggested that the platelet counts reflect the disease development as well as its severity thus; IL-23 levels could serve as a potential index to evaluate the disease state. In contrast, El Husseiny et al. 2018 [31] found statistically insignificant correlation between platelets count and the level of IL-17 in ITP cases.

In ITP patients, the genotype frequencies of the $I L$ $17 A$ rs2275913 polymorphism were AA (76.7\%), AG $(16.7 \%)$ and GG were found in $(6.6 \%)$ while, in the control group the genotype frequencies of the $I L-17 \mathrm{~A}$ rs2275913 polymorphism, were AA (72\%) and AG (28\%). There was no significant difference between frequencies of the three $I L-17 A$ genotypes and alleles distribution in ITP patients compared to control group despite $I L-17 A$ GG genotype was only found in cases. This comes in concordance with the study of Liu et al. 2016 [40].

The frequency of allele A of $I L-17 A$ gene was $85 \%$ in the cases group and $86 \%$ in the control group, while the frequency of allele $\mathrm{G}$ was $15 \%$ in the cases group and $14 \%$ in the control group which were not significantly different when cases compared to controls. Similarly, Aziz et al. 2018 [27] carried out statistical analysis of the genotype frequencies (GG, AG, AA) of the $I L-17 A$ rs2275913 polymorphism and its alleles (A, G) in cases with acute ITP compared to controls and found no significant differences between the two groups. Aziz et al., 2018 study [27] was performed on Egyptian children. The frequencies of A allele were 71.3 and $75.5 \%$ when ITP cases were compared to controls; respectively. Other studies were performed on Egyptian population regarding A allele frequency of $I L-17 A$ rs2275913 polymorphism in Egyptian population. The targeted patients in these studies were those with systemic lupus erythematosus [41], acute myeloid leukemia [42] and vitiligo [43]. Similar to our study and Aziz et al., 2018 study [27], their reported frequencies were $65 \%$ within healthy control group in the study concerned about acute myeloid leukemia patients and $53.8 \%$ within healthy control group in vitiligo concerned one. In contrast, A allele frequency of $I L-17 A$ rs2275913 gene shows a minor percentage (29\%) within healthy controls in systemic lupus erythematosus study which comes in consistent with $I L$ $17 A$ rs2275913 polymorphism allele frequencies that are reported in SNP public database (https://www.ncbi.nlm. nih.gov/snp/rs2275913\#frequency_tab). Altogether, these findings indicate that North Africans may have different IL-17A rs2275913 polymorphism characteristics, particularly Egyptians. Therefore, additional Egyptian population data base collection about IL-17A rs2275913 SNP is necessary.

On top, we investigated the association between $I L-$ $17 A$ rs2275913 polymorphism and the clinical responses to treatment. Steroid treatment is the first-line therapy strategy, thus most of our enrolled patients (86.7\%) received it. We found statistically insignificant difference with the outcome of treatment. Regarding the disease course and prognosis of ITP patients during their follow-up, we evaluated the genotype and allele distribution among three ITP subgroups: acute, persistent, and chronic ITP. Statistically insignificant differences were found with comparison between them. IL-17A AA genotype appeared to be more closely associated with early recovery than with persistent course of the disease (84.6\% vs. $66.7 \%$ ) and AG genotype more closely associated with persistent disease course (33.3\% vs. $15.4 \%)$. Our results come in line with those of Aziz et al. 2018 [27]. They found that the IL-17A rs2275913 GG genotype was associated with early recovery $(p=0.04)$. Also, we investigated the association of IL-17A genotypes with the clinical features of acute ITP. There was no significant association between the frequencies of genotypes and gender, age as well as disease severity. Likewise, Aziz et al. 2018 [27] investigated the association of the $I L-17 A$ rs2275913 genotypes with the clinical features of acute ITP. They found no significant association between genotypes frequencies and gender, age, along with disease severity, or the outcome following treatment except for GG genotype which was expressed only in males and associated with severe thrombocytopenia (100\%).

To the extent of our knowledge, our study is one of very few studies concerned about IL-23/Th17 plus IL$17 \mathrm{~A}$ and its rs2275913 polymorphism in Egyptian children with ITP. However, this study was conducted on a relatively small number of ITP children recruited from one hospital. Among IL-17 family of cytokines, only $I L-$ $17 A$ rs2275913 polymorphism was analyzed in the present study because it was reported as the most common IL-17 gene polymorphism within ITP patients. Therefore, future studies on multicenter larger sample size Egyptian population are still warranted. These studies should focus on IL-23/Th17 and IL-17 in addition to different genes polymorphisms related to IL-17 family with before and after effective treatment evaluations.

\section{Conclusion}

A higher percentage of Th17 cells along with elevated levels of IL-23 and IL-17A in ITP patients compared to healthy controls, as well as the significant positive correlation of IL-23 levels with IL-17A levels and Th17 cells percentage plus its significant negative correlation with platelet count suggest that IL-23 may be involved in the pathogenesis of ITP. However, this needs further 
comprehensive mechanistic investigations. These findings also provide new insights on the possibility of employing anti-IL-23 drugs or targeting the IL-17 axis for treatment of ITP which should be confirmed through animal models or in vitro trials. Moreover, no significant association was demonstrated in the current study between $I L-17 A$ rs2275913 polymorphism and the risk of ITP in Egyptian children which in turn requires prospective studies.

\begin{abstract}
Abbreviations
ITP: Immune thrombocytopenic purpura; IL-17A: interleukin-17A; IL23: interleukin-23; Th17: T helper 17; GP: platelet glycoprotein; CD8, 4, 3: Cluster of differentiation 8, 4, 3; Treg: regulatory T cells; IL-17R: IL-17 receptor; G-CSF: granulocyte colony-stimulating factor; CXC: chemotaxis; IVIG: intravenous immunoglobulin; ELISA: enzyme-linked immunosorbent assay; PCR-RFLP: polymerase chain reaction-restriction fragment length polymorphism; SD: standard deviation; ANOVA: analysis of variance; MPV: Mean platelet volume; SNP: single nucleotide polymorphism
\end{abstract}

\section{Acknowledgements}

The authors express their gratitude to all enclosed subjects in this study.

\section{Authors' contributions}

Ahlam M. Ismail: recruited the patients and collected the data and designed and guided the research. Aliaa M. Higazi: analyzed the data and carried the laboratory investigations and statistical analysis. Hanan M. Nomeir: contribute in the laboratory investigations. Naglaa M. Farag: contribute in the laboratory investigations and designed and guided the research. All authors participate in writing the article, read and approved the final manuscript.

\section{Funding}

No financial or institutional departmental funds were obtained.

\section{Availability of data and materials}

Key data generated or analyzed during this study are included in this published article.

\section{Declarations}

\section{Ethics approval and consent to participate}

The study was approved by local ethical committee at Minia UniversityFaculty of Medicine. A written informed consent was signed from the parents or guardians of the children.

\section{Consent for publication}

Participants provided informed consent for the publication of the study. Authors agree to publish this work in Italian journal of pediatrics.

\section{Competing interests}

The authors declare no conflict of interest. No financial or non-financial benefits have been received or will be received from any party related directly or indirectly to the subject of this article.

\section{Author details}

'Minia Maternity and Children University Hospital, Pediatrics department, Faculty of Medicine, Minia University, Minia, Egypt. ${ }^{2}$ Clinical and Chemical Pathology department, Faculty of Medicine, Minia University, Minia, Egypt. ${ }^{3}$ Medical Biochemistry department, Faculty of Medicine, Alexandria University, Alexandria, Egypt.

Received: 21 April 2021 Accepted: 13 August 2021

Published online: 26 August 2021

\section{References}

1. Malinowska I, Obitko-Płudowska A, Buescher ES, Wasik M, Rokicka-Milewska R. Release of cytokines and soluble cytokine receptors after intravenous anti-D treatment in children with chronic thrombocytopenic purpura. Hematol J. 2001;2(4):242-9. https://doi.org/10.1038/sj.thj.6200106.
2. Michel M. Immune thrombocytopenic purpura: epidemiology and implications for patients. Eur J Haematol Suppl. 2009;82:3-7. https://doi. org/10.1111/j.1600-0609.2008.01206.x.

3. Rodeghiero F, Stasi R, Gernsheimer T, Michel M, Provan D, Arnold DM, et al. Standardization of terminology, definitions and outcome criteria in immune thrombocytopenic purpura of adults and children: report from an international working group. Blood. 2009;113(11):2386-93. https://doi.org/1 0.1182/blood-2008-07-162503.

4. Cines D, Bussel J, Liebman H, Luning PE. The ITP syndrome: pathogenic and clinical diversity. Blood. 2009;113(26):6511-21. https://doi.org/10.1182/ blood-2009-01-129155.

5. Culic S, Labar B, Marusic A, Salamunic I. Correlations among age, cytokines, lymphocyte subtypes, and platelet counts in autoimmune thrombocytopenic purpura. Pediatr Blood Cancer. 2006;47(S5):671-4. https:// doi.org/10.1002/pbc.20999.

6. Zhao C, Li X, Zhang F, Wang L, Peng J, Hou M. Increased cytotoxic Tlymphocyte-mediated cytotoxicity predominant in patients with idiopathic thrombocytopenic purpura without platelet autoantibodies. Haematologica. 2008;93(9):1428-30. https://doi.org/10.3324/haematol.12889.

7. Ji X, Zhang L, Peng J, Hou M. T cell immune abnormalities in immune thrombocytopenia. J Hematol Oncol. 2014;7(1):72. https://doi.org/10.1186/ s13045-014-0072-6.

8. Ogawara H, Handa H, Morita K, Hayakawa M, Kojima J, Amagai H, et al. High Th1/Th2 ratio in patients with chronic idiopathic thrombocytopenic purpura. Eur J Haematol. 2003;71(4):283-8. https://doi.org/10.1034/j.16000609.2003.00138.x

9. Sarkar S, Cooney LA, Fox DA. The role of T helper type 17 cells in inflammatory arthritis. Clin Exp Immunol. 2010;159(3):225-37. https://doi. org/10.1111/j.1365-2249.2009.04016.x.

10. Korn T, Bettelli E, Oukka M. IL-17 and Th17 cells. Annul Rev Immunol. 2009; 27(1):485-517. https://doi.org/10.1146/annurev.immunol.021908.132710.

11. Gaffen SL. Structure and signalling in the IL-17 receptor family. Nat Rev Immunol. 2009;9(8):556-67. https://doi.org/10.1038/nri2586 Epub 2009 Jul 3. Erratum in: Nat Rev Immunol. 2009 Oct;9(10):747. PMID: 19575028; PMCID: PMC2821718.

12. Ivanov S, Lindén A. Interleukin-17 as a drug target in human disease. Trends Pharmacol Sci. 2009;30(2):95-103. https://doi.org/10.1016/j.tips.2008.11.004.

13. Heylen M, Ruyssers NE, Gielis EM, Vanhomwegen E, Pelckmans PA, Moreels $\mathrm{TG}$, et al. Of worms, mice and man: an overview of experimental and clinical helminth-based therapy for inflammatory bowel disease. Pharmacol Ther. 2014;143(2):153-67. https://doi.org/10.1016/.jpharmthera.2014.02.011.

14. Kimura A, Kishimoto T. IL-6: regulator of Treg/Th17 balance. Eur I Immunol. 2010;40(7):1830-5. https://doi.org/10.1002/eji.201040391.

15. Tang C, Chen S, Qian H, Huang W. Interleukin-23: as a drug target for autoimmune inflammatory diseases. Immunology. 2012;135(2):112-24. https://doi.org/10.1111/j.1365-2567.2011.03522.x.

16. Xu S, Cao X. Interleukin-17 and its expanding biological functions. Cell Mol Immunol. 2010;7(3):164-74. https://doi.org/10.1038/cmi.2010.21.

17. Roeleveld DM, van Nieuwenhuijze AE, van den Berg WB, Koenders MI. The Th17 pathway as a therapeutic target in rheumatoid arthritis and other autoimmune and inflammatory disorders. BioDrugs. 2013;27(5):439-52. https://doi.org/10.1007/s40259-013-0035-4.

18. Qian C, Jiang T, Zhang W, Ren C, Wang Q, Qin Q, et al. Increased IL-23 and IL17 expression by peripheral blood cells of patients with primary biliary cirrhosis. Cytokine. 2013;64(1):172-80. https:/doi.org/10.1016/..cyto.2013.07.005.

19. Fransen $K$, van Sommeren $S$, Westra $H J$, Veenstra M, Lamberts $L E$, Modderman R, et al. Correlation of genetic risk and messenger RNA expression in a Th17//L23 pathway analysis in inflammatory bowel disease. Inflamm Bowel Dis. 2014;20(5):777-82. https://doi.org/10.1097/MIB. 0000000000000013.

20. Zhang $X$, Y U P, Wang Y, Jiang W, Shen F, Wang Y, et al. Genetic polymorphisms of interleukin $17 \mathrm{~A}$ and interleukin $17 \mathrm{~F}$ and their association with inflammatory bowel disease in a Chinese Han population. Inflamm Res. 2013;62(8):743-50. https://doi.org/10.1007/s00011-013-0629-9.

21. Bunte $K$, Beikler T. Th17 cells and the IL-23/L-17 Axis in the pathogenesis of periodontitis and immune-mediated inflammatory diseases. Int J Mol Sci. 2019;20(14):3394. https://doi.org/10.3390/ijms20143394.

22. Pawlik A, Kotrych D, Malinowski D, Dziedziejko V, Czerewaty M, Safranow K IL17A and IL17F gene polymorphisms in patients with rheumatoid arthritis. BMC Musculoskeletal Disord. 2016;17(1):208. https://doi.org/10.1186/s12891016-1064-1. 
23. Nordang GB, Viken MK, Hollis-Moffatt JE, Merriman TR, Førre $\varnothing T$, Helgetveit $\mathrm{K}$, et al. Association analysis of the interleukin 17A gene in Caucasian rheumatoid arthritis patients from Norway and New Zealand. Rheumatology. 2009;48(4):367-70. https://doi.org/10.1093/rheumatology/ ken512.

24. Arisawa T, Tahara T, Shibata T, Nagasaka M, Nakamura M, Kamiya Y, et al, The influence of polymorphisms of interleukin-17A and interleukin-17F genes on the susceptibility to ulcerative colitis. J Clin Immunol. 2008;28(1): 44-9. https://doi.org/10.1007/s10875-007-9125-8.

25. Ye X, Zhang L, Wang H, Chen Y, Zhang W, Zhu R, et al. The role of IL- 3/ Th17 pathway in patients with primary immune thrombocytopenia. PLoS One. 2015;10(1):e0117704. https://doi.org/10.1371/journal.pone.0117704.

26. Hu Y, Li H, Zhang L, Shan B, Xu X, Li H, et al. Elevated profiles of Th22 cells and correlations with Th17 cells in patients with immune thrombocytopenia. Hum Immunol. 2012;73(6):629-35. https://doi.org/10.101 6/j.humimm.2012.04.015.

27. Aziz SP, Ahmed HA, Mahmoud RA, Mahmoud MA. Association of IL-17A and IL-17F Gene Polymorphisms with Acute Immune Thrombocytopenia in Egyptian Children. Open J Blood Dis. 2018;8:49-60. https://doi.org/10.4236/ ojbd.2018.83006

28. Neunert C, Terrell DR, Arnold DM, Buchanan G, Cines DB, Cooper N, et al. American Society of Hematology 2019 guidelines for immune thrombocytopenia. Blood Adv. 2019;3(23):3829-66. https://doi.org/10.1182/ bloodadvances.2019000966 Erratum in: Blood Adv. 2020; 4(2):252.

29. Segel GB, Feig SA. Controversies in the diagnosis and management of childhood acute immune thrombocytopenic purpura. Pediatr Blood Cancer. 2009;53(3):318-24. https://doi.org/10.1002/pbc.21934.

30. Misra DP, Chaurasia S, Misra R. Increased circulating Th17 cells, serum IL17A, and IL-23 in Takayasu arteritis. Autoimmune Dis. 2016;2016:7841718. https://doi.org/10.1155/2016/7841718.

31. El Husseiny Noha M. El Sobky Amira; Khalaf Ahmed; amdy Heba; El Husseiny Sherin; Genina Ashraf. Immune thrombocytopenia. Egyptian experience with study of IL-17, TGFB, cytokines in chronic and persistent immune thrombocytopenia patients. Int J Adv Res. 2018;6(3):1087-90. https://doi. org/10.21474/IJAR01/6770

32. Baig MA. Platelet Indices-Evaluation of Their Diagnostic Role in Pediatric Thrombocytopenias (One Year Study). Int J Res Med Sci. 2015;3(9):2284-9. https://doi.org/10.18203/2320-6012.ijrms20150618.

33. McMillan R. The pathogenesis of chronic immune (idiopathic) thrombocytopenic purpura. Semin Hematol. 2007;44:3-11.

34. Zhu X, Ma D, Zhang J, Peng J, Qu X, Ji C, et al. Elevated interleukin-21 correlated to Th17 and Th1 cells in patients with immune thrombocytopenia. J Clin Immunol. 2010;30(2):253-9. https://doi.org/10.1 007/s10875-009-9353-1.

35. Liu XG, Ren J, Yu Y, Sun L, Shi Y, Qin P, et al. Decreased expression of interleukin-27 in immune thrombocytopenia. Br J Haematol. 2011;153(2): 259-67. https://doi.org/10.1111/j.1365-2141.2011.08614.x.

36. Rocha AM, Souza C, Rocha GA, de Melo FF, Clementino NC, Marino MC, et al. The serum levels of the cytokines involved in the Th17 and Th1 cell commitment are increased in individuals with borderline thrombocytopenia. J Hematol Oncol. 2013;6(1):28. https://doi.org/10.1186/1 756-8722-6-28.

37. Zhang J, Ma D, Zhu X, Qu X, Ji C, Hou M. Elevated profile of Th17, Th1 and Tc1 cells in patients with immune thrombocytopenic purpura. Haematologica. 2009;94(9):1326-9. https://doi.org/10.3324/haematol.2009. 007823.

38. Yabu M, Shime H, Hara H, Saito T, Matsumoto M, Seya T, et al. IL-23dependent and -independent enhancement pathways of IL-17A production by lactic acid. Int Immunol. 2011;23(1):29-41. https://doi.org/10.1093/ intimm/dxq455

39. Huang WY, Sun QH, Chen YP. Expression and Significance of CD4+ CD25+ CDI27low Regulatory T Cells, TGF- $\beta$ and Notch 1 mRNA in Patients with Idiopathic Thrombocytopenic Purpura. Zhongguo Shi Yan Xue Ye Xue Za Zhi. 2015;23(6):1652-6. https://doi.org/10.7534/j.issn.1009-2137.2015.06.023 Chinese. . PMID: 26708888

40. Liu S, Xiong YZ, Li T, Li Y, Gu SQ, Wang YM, et al. Interleukin-17A and -17F gene polymorphisms in Chinese population with chronic immune thrombocytopenia. Ann Clin Lab Sci. 2016;46(3):291-7 PMID: 27312555.

41. Elkoumi MA, Allah MA, Mohamed FY, Boraey NF, Abdellatif SH, Shehab MM, et al. Association of interleukin-17A gene polymorphisms and susceptibility to systemic lupus erythematosus in Egyptian children and adolescents: a
multi-Centre study. Lupus. 2020;29(7):767-75. https://doi.org/10.1177/09612 03320922305.

42. Elsissy M, Abdelhafez A, Elmasry M, Salah D. Interleukin-17 gene polymorphism is protective against the susceptibility to adult acute myeloid Leukaemia in Egypt: a case-control study. Open Access Maced J Med Sci. 2019;7(9):1425-9. https://doi.org/10.3889/oamjms.2019.306.

43. Mohammed F, Amr KS, Abdel Raheem H, Shehata H, ElRasheedy M, Elias TR, et al. Study of interleukin-17 gene polymorphism and susceptibility to vitiligo in a sample of the Egyptian population. J Egypt Women's Dermatol Soc. 2017;14(1):45-8. https://doi.org/10.1097/01.EWX.0000503399.60863.9f.

\section{Publisher's Note}

Springer Nature remains neutral with regard to jurisdictional claims in published maps and institutional affiliations.
Ready to submit your research? Choose BMC and benefit from:

- fast, convenient online submission

- thorough peer review by experienced researchers in your field

- rapid publication on acceptance

- support for research data, including large and complex data types

- gold Open Access which fosters wider collaboration and increased citations

- maximum visibility for your research: over $100 \mathrm{M}$ website views per year

At BMC, research is always in progress.

Learn more biomedcentral.com/submissions 